\title{
Pendidikan Karakter pada Muslimah di Komunitas Hijabers Kota Salatiga
}

\author{
Ani Rochmani Galuh Rakasiwi \\ SMP Sultan Agung I Tirtomoyo \\ Email: rakasiwi@yahoo.com \\ Heru Saputra \\ Osmania University, India \\ Email: herusaputra@gmail.com
}

\begin{abstract}
Abstrak
Tujuan dari penelitian ini adalah untuk mengetahui persepsi hijabers tentang pendidikan karakter, model pendidikan karakter dalam komunitas Hijabers, faktor penghambat dan pendorong, serta untuk mencari solusi terhadap faktor penghambatnya dalam komunitas hijabers Salatiga. Penelitian ini menggunakan pendekatan kualitatif yang menghasilkan data deskriptif baik lisan maupun tertulis dari orang-orang dan perilaku mereka. Kemudian data tersebut dianalisa melalui penelitian fenomenologis. Hasil penelitian menunjukkan bahwa: 1) persepsi pendidikan karakter para hijabers adalah proses pembentukan dan perubahan refleksi setiap individu untuk menjadi lebih baik; 2) model pendidikan karakter yang diterapkan meliputi dua penguatan, yaitu penguatan agama dan solidaritas; 3) Faktor-faktor penghambat dalam implementasi pendidikan karakter adalah sulitnya mengumpulkan peserta, kurangnya tanggung jawab, kurangnya disiplin, kurangnya
\end{abstract}


keterbukaan, serta pro dan kontra mengenai Komunitas Hijabers. Kemudian ada juga faktor pendorong, yaitu dan visi mereka yang dapat diterima serta keinginan kuat mereka untuk memasyarakatkan hijab melalui Komunitas Hijabers; 4) Solusi untuk mengatasi hambatan ini adalah dengan berkumpul dan berbagi, bertanggungjawab sesuai tugas, menunjukkan empati tidak hanya sekedar pamer kecantikan, menunjukkan mereka berada di kelas atas, meski ada pro-kontra, mereka juga berusaha untuk mengembangkan karakter untuk menjadi lebih baik.

This study aims to determine the hijabers' perception about character education, model of character education in Salatiga Hijabers Community, its inhibiting and supporting factors and how to find the solutions to those factors. It utilizes qualitative approach resulting descriptive data about people and their behavior in both spoken and written, then it is analyzed through a phenomenological research. The results show that: 1) the perception of character education proposed by hijabers is a process of formation and change in individual reflection to be better; 2) the models applied to the character education are: religious strengthening of and solidarity; 3) The inhibiting factors in character education are difficulty in gathering, lack of discipline and transparency, the pros and cons regarding hijabers. Then the supporting factors are their accepted mission and vision and their strong willingness to socialize hijab; 4) The solution to the inhibiting factors are by gathering and sharing, responsibility to take turn in every event, showing empathy not merely show off beauty, perceiving that they are in high class, but behind the pros and cons they always try to develop their character to be better.

Kata Kunci: pendidikan karakter, hijabers, komunitas

\section{Pendahuluan}

Pendidikan merupakan suatu proses atau usaha dari manusia dewasa yang telah sadar akan kemanusiaannya dalam membimbing, melatih, mengajar, dan menanamkan nilai-nilai serta dasar-dasar pandangan hidup pada generasi muda, agar nantinya menjadi manusia 
yang sadar dan bertanggung jawab akan tugas-tugas hidupnya sebagai manusia sesuai dengan sifat- sifat hakiki dan ciri-ciri kemanusiaannya. Pendidikan juga dapat diartikan sebagai proses internalisasi budaya ke dalam diri seseorang dan masyarakat sehingga membuat orang dan masyarakat beradab (Muslich, 2011:69). Pendidikan berfungsi sebagai sarana untuk menyiapkan potensi-potensi yang dimiliki oleh individu dan sebagai sektor penting dalam pembentukan dan pengembangan karakter, khususnya pada muslimah di komunitas hijabers kota Salatiga. Menurut pandangan Islam, muslimah merupakan titik sentral dalam pembentukan suatu bangsa.

Jika dilihat di era teknologi informasi yang semakin berkembang dalam kehidupan masyarakat ini, memiliki dampak baik positif maupun negatif terhadap pertumbuhan karakter bangsa. Semakin hari makin terasa kemunduran moral, sikap, dan perilaku masyarakat. Kemunduran tersebut ditandai oleh ketidakpedulian antar sesama, sikap tidak sopan santun, tidak gotongroyong, tidak menjaga amanah, penyalahgunaan wewenang, dan yang terjadi pada para pelajar diantaranya menyontek, tidak jujur, bolos sekolah, tawuran, dan lain sebagainya. Begitu pula yang terjadi pada para muslimah remaja hingga muslimah dewasa yang ditandai dengan ketidakpedulian mereka terhadap etika berbusana.Permasalah tersebut tentu tidak lepas dari pendidikan dan pembelajaran yang mereka dapatkan namun hanya bersifat akademik semata, sedangkan pendidikan karakter mereka terabaikan. Menurut Raka dalam buku Pendidikan Karakter: Menjawab Tantangan Krisis Multidimensional, menyatakan bahwa krisis karakter bangsa ditandai 
oleh beberapa hal diantaranya: "terlampau terlena oleh Sumber Daya Alam yang melimpah,pembangunan ekonomi yang terlalu bertumpu pada modal fisik,surutnya idealisme, berkembangnya pragmatisme,kurang berhasil belajar dari pengalaman bangsa sendiri” (Muslich, 2011:72).

Dilihat dari permasalahan remaja khususnya pada muslimah, tidak terlepas dari pengaruh lingkungan mereka baik keluarga, teman pergaulan, acara-acara di televisi, bahkan internet yang banyak menyajikan berbagai informasi yang menjadi tumbuh kembang dalam pendidikan karakter remaja khususnya muslimah saat ini.

UU Nomor 20 tahun 2003 tentang Sistem Pendidikan Nasional bab II pasal 3 disebutkan bahwa pendidikan nasional berfungsi mengembangkan kemampuan dan membentuk watak serta peradaban bangsa yang bermartabat dalam rangka mencerdaskan kehidupan bangsa, bertujuan untuk berkembangnya potensi peserta didik agar menjadi manusia yang beriman dan bertakwa kepada Tuhan Yang Maha Esa, berakhlak mulia, sehat, berilmu, cakap, kreatif, mandiri, dan menjadi warga negara yang demokratis serta bertanggung jawab.

Makna dari isi undang-undang tersebut bahwa pendidikan nasional mendorong terwujudnya generasi penerus bangsa yang memiliki karakter religius, berakhlak mulia, cendekiawan, mandiri, dan demokratis (Zuchdi dkk, 2013:15).Berkaitan dengan sifat-sifat mulia dan semakin pesatnya perkembangan zaman terutama fashion dikalangan muslimah maka muncul komunitas muslimah yang disebut sebagai "komunitas hijaber Salatiga"yaitu kumpulan dari wanita-wanita muslim berjilbab di kota Salatiga. Komunitas ini memiliki banyak anggota dengan berbagai 
latar belakang yang menjadi faktor mereka dalam bergabung, yang mungkin sebelum mereka bergabung ada yang belum mengenakan jilbab dan setelah bergabung menjadi termotivasi untuk berjilbab.

Realitasnya banyak dari muslimah yang mengenakan jilbab, banyak pula muslimah yang berjilbab tapi melakukan hal-hal yang tidak sepantasnya, dan tidak sedikit pula yang masih belum berjilbab bahkan banyak yang mengumbar tubuhnya dengan berpakaian serba ketat dan tipis. Globalisasi juga membuat muslimah mengikuti kiblat yang salah, banyak muslimah yang terbawa arus globalisasi yang berefek negatif, misalnya saja mode-model pakaian yang yang ditawarkan oleh produkproduk yang berbalut busana muslim namun kenyataannya jauh dari pakaian muslim yang sebenarnya, dengan model-model jilbab yang tidak standar. Namun anehnya banyak muslimah yang lebih memilih modelmodel pakaian seperti ini, dengan anggapan agar tidak terlihat kuno/ketinggalan zaman, hal ini menunjukkan merosotnya karakter pada bangsa Indonesia dan khususnya di kota Salatiga.

Terkait hal tersebut, terdapat nilai-nilai karakter dalam membentuk pribadi yang beradab diantaranya: religius, jujur, toleransi, disiplin, kerja keras, kreatif, mandiri, demokratis, rasa ingin tahu, semangat kebangsaan, cinta tanah air, menghargai prestasi, bersahabat/komunikatif, cinta damai, gemar membaca, peduli lingkungan, peduli sosial, dan tanggung jawab (Samani dan Hariyanto, 2013:9). Pendidikan dalam membangun karakter lebih menekankan pada pengembangan kebiasaan baik dalam kehidupan sehari-hari, dalam pendidikan karakter tidak cukup mengetahui apa yang baik namun yang 
terpenting adalah menyemaikan kebaikan itu di hati dan menerapkannya dalam tindakan. Oleh karena itu pendidikan karakter sangat diperlukan terutama pada zaman sekarang yang semakin merosotnya moralitas khususnya pada muslimah.

Berdasarkan latar belakang di atas, maka peneliti dapat memfokuskan masalah dalam penelitian ini, yaitu pertama bagaimanakah persepsi hijabers tentang pendidikan karakter di komunitas hijabers kota Salatiga. Yang kedua bagaimana model pendidikan karakter di komunitas hijabers kota Salatiga. Yang ketiga apa adalah faktor-faktor penghambat dan pendorong pendidikan karakter di komunitas hijabers kota Salatiga. Dan yang terakhir bagaimanakah solusi dalam mengatasi faktor-faktor penghambat pendidikan karakter di komunitas hijabers kota Salatiga.

\section{Metode Penelitian}

Penelitian ini menggunakan metode kualitatif yang akan menghasilkan data baik tulisan maupu lisan dlam bentuk deskripsi. Penelitian kualitatif didefinisikan sebagai suatu proses yang mencoba untuk mendapatkan pemahaman yang lebih baik mengenai kompleksitas yang ada dalam interaksi manusia (Catherine Marshal, 1995). Poerwandari (2007) mengungkapkan bahwa penelitian kualitatif menghasilkan dan mengolah data yang sifatnya deskriptif, seperti transkip wawancara, catatan lapangan, gambar, foto, rekaman video, dan lain sebagainya. Definisi di atas menunjukkan beberapa kata kunci dalam penelitian kualitatif, yaitu: proses, pemahaman, kompleksitas, interaksi, dan manusia. Proses dalam melakukan penelitian merupakan penekanan 
dalam penelitian kualitatif oleh karena itu dalam melaksanakan penelitian, peneliti lebih berfokus pada proses dari pada hasil akhir. Proses yang dilakukan dalam penelitian ini memerlukan waktu dan kondisi yang berubah-ubah maka definisi penelitian ini akan berdampak pada desain penelitian dan cara-cara dalam melaksanakannnya yang juga berubah-ubah atau bersifat fleksibel. Sasaran penelitian kualitatif utama ialah manusia karena manusialah sumber masalah, artefak, peninggalanpeninggalan peradaban kuno dan lain sebagainya. Intinya sasaran penelitian kualitatif ialah manusia dengan segala kebudayaan dan kegiatannya.

Penelitian kualitatif dipandang lebih sesuai untuk mengetahui bagaimana berjalannya pendidikan karakter pada komunitas hijabers salatiga. Hal ini sesuai dengan yang diungkapkan oleh Poerwandari (2007) bahwa pendekatan yang sesuai untuk penelitian yang tertarik dalam memahami manusia dengan segala kekompleksitasannya sebagai makhluk subjektif adalah pendekatan kualitatif.

Karakter merupakan hal yang bersifat subjektif bagi masingmasing individu, sehingga dengan penelitian kualitatif ini diharapkan berjalannya proses pendidikan karakter pada komunitas hijabers salatiga dapat direkam dengan baik dan kedepan bisa menjadi bahan evaluasi dalam rangka menyelenggarakan kegiatan yang lebih baik lagi.

\section{Hasil Penelitian dan Pembahasan}

\section{A. Persepsi Tentang Pendidikan Karakter}


Pembicaraan mengenai pendidikan karakter atau pendidikan yang berbasis pada karkater menjadi pokok bahasan yang banyak dibicarakan baik dalam lingkup pendidikan maupun masyarakat pada umumnya, karena perilaku pada remaja saat ini sudah sangat memprihatinkan, sudah sangat jauh dari akhlak yang mulia menurut pandangan Islam. Ini dikarenakan di tingkat pendidikan terutama sekolah hanya mengutamakan tingkat intelegensi siswa sedangkan pendidikan karakter mereka terabaikan. Berkaitan dengan ini, maka akan dijelaskan terlebih dahulu pengertian pendidikan karakter yang dijelaskan secara terpisah.

Persepsi menurut McMahon adalah proses menginterpretasikan rangsangan (input) dengan menggunakan alat penerimaan informasi (sensory information). Sedangkan menurut Morgan, King, dan Robinson, persepsi merupakan bagaimana kita melihat, mendengar, merasakan, mengecap, dan mencium dunia di sekitar kita, dengan kata lain persepsi dapat didefinisikan sebagai segala sesuatu yang dialami oleh manusia (Adi, 1994:105). Menurut Brian fellow, persepsi adalah proses yang memungkinkan suatu organisme menerima dan menganalisis informasi.Kenneth K. Sereno danEdward M. Badaken,persepsi adalah sarana yang memungkinkan kita memperoleh kesadaran akan sekeliling dan lingkungan kita.Phillip Goodracre dan jennifer follers, persepsi adalah proses mental yang digunakan untuk mengenali rangsangan. Joseph A. Devito,persepsi adalah proses yang menjadikan kita sadar akan banyaknya stimulus yang mempengaruhi indera kita (Mulyana, 2013:180). Jadi dapat disimpulkan bahwa persepsi adalah tanggapan atau 
pandangan seseorang mengenai sesuatu yang dialami oleh setiap individu.

Adapun pengertian pendidikan, diantaranya diungkapkan oleh Driyarkara (dalam Ikhsan, 2003:4), bahwa pendidikan adalah upaya memanusiakan manusia muda . Dictionary of Education menyebutkan bahwa pendidikan adalah proses di mana seseorang mengembangkan kemampuan sikap dan bentuk-bentuk tingkah laku lainnya di dalam masyarakat di mana ia hidup, proses sosial di mana orang dihadapkan pada pengaruh lingkungan yang terpilih dan terkontrol (khususnya yang datang dari sekolah), sehingga ia dapat memperoleh atau mengalami perkembangan kemampuan sosial dan kemampuan individu yang optimum.

Mengenai karakter, Suyanto dalam buku Pendidikan Karakter: Menjawab Tantangan Krisis Multidimensional, menyatakan bahwa karakter adalah cara berpikir dan berperilaku yang menjadi ciri khas dari tiap individu untuk hidup dan bekerjasama, baik dalam lingkup keluarga, masyarakat, bangsa, dan negara (dalam Muslich, 2011:70).

Hermawan Kartajaya mengemukakan bahwa karakter adalah ciri khas yang dimiliki oleh suatu benda atau individu (manusia). Ciri khas tersebut adalah asli, dan mengakar pada kepribadian benda atau individu tersebut dan merupakan mesin pendorong bagaimana seseorang bertindak, bersikap, berujar, serta merespon sesuatu (dalam Gunawan, 2012:2).

Pendidikan karakter saat ini merupakan topik yang banyak dibicarakan di kalangan pendidik, karena pendidikan karakter sangat 
dibutuhkan dalam mendidik karkater anak bangsa agar menjadi penerus yang berkarakter mulia. Ada beberapa pengertian pendidikan karakter menurut para ahli, diantaranya:

Menurut Ratna Megawangi, pendidikan karakter merupakan sebuah usaha untuk mendidik anak-anak agar dapat mengambil keputusan dengan bijak dan mempraktikkannya dalam kehidupan seharihari, sehingga mereka dapat memberikan kontribusi yang positif kepada lingkungannya (dalam Kesuma dkk, 2012:5).

Menurut Lickona, pendidikan karakter merupakan upaya yang sungguh-sungguh untuk membantu seseorang memahami, peduli, dan bertindak dengan landasan inti nilai-nilai etis, atau upaya yang dirancang secara sengaja untuk memperbaiki karakter para siswa (dalam Samani dan Hariyanto, 2013:44).

Ada beberapa nilai karakter yang penting untuk dibahas dalam tulisan ini guna memperjelas inti pembahasan, diantaranya:

Yang pertama adalah nilai religious, yang merupakan perilaku yang patuh dalam melaksanakan ajaran agama yang dianutnya, toleran terhadap pelaksanaan ibadah agama lain dan hidup rukun dengan pemeluk agama lain (Wibowo, 2012:43).Jadi sebagai seorang muslim diwajibkan untuk selalu menghormati agama orang lain, dan juga diwajibkan bagi setiap umat beragama khususnya Islam untuk selalu mematuhi segala perintah-Nya dan menjauhi segala larangan-Nya.

Nilai yang kedua adalah jujur, yang dalam pandangan umum sering dimaknai sebagai adanya kesamaan antara realitas (kenyataan) dengan ucapan atau dengan kata lain “apa adanya” (Kesuma dkk, 
2012:16). Orang yang memilki karkater jujur dicirikan oleh tiga perilaku, yaitu jika bertekad untuk melakukan sesuatu, tekadnya adalah kebenaran dan kemaslahatan, jika berkata tidak berbohong (benar apa adanya), jika adanya kesamaan antara yang dikatakan hatinya dengan apa yang dilakukannya. Karakter ini merupakan salah satu karakter pokok untuk menjadikan seseorang cinta kebenaran, apapun resiko yang akan diterima dirinya dengan kebenaran yang ia lakukan (Kesuma dkk, 2012:17). Jujur merupakan karakter yang dapat menarik orang lain untuk percaya, karena orang jujur adalah orang yang dapat menjaga amanah.

Nilai ketiga adalah toleransi, yang merupakan perilaku yang menghargai perbedaan agama, suku, etnis, pendapat, sikap, dan tindakan orang lain yang berbeda dari dirinya (Wibowo, 2012:43). Toleransi berarti sikap atau perbuatan yang melarang adanya diskriminasi terhadap orang-orang/kelompok yang berbeda dengannya.

Selanjutnya adalah disiplin. Disiplin merupakan tindakan yang menunjukkan perilaku tertib dan patuh pada berbagai ketentuan dan peraturan (Asmani, 2011:37). Disiplin adalah kunci sukses karena disiplin akan berpengaruh besar terhadap kehidupan seseorang. Disiplin akan menumbuhkan sifat yang teguh dalam memegang prinsip, tekun dalam berusaha dan belajar, pantang mundur dalam kebenaran, rela berkorban demi kepentingan agama, dan pantang putus asa.

Lalu kerja keras yang merupakan suatu upaya yang terus dilakukan (tidak pernah menyerah) dalam menyelesaikan pekerjaan/tugasnya sampai tuntas, melainkan mengarahkan pada visi besar yang harus dicapai untuk kebaikan/kemaslahatan manusia dan 
lingkungannya (Kesuma dkk, 2012:17). Bekerja keras berarti berusaha atau berjuang dengan sungguh-sungguh. Berjuang dengan sungguhsungguh untuk mencapai suatu tujuan, kemudian disertai dengan berserah diri (tawakal) kepada Allah SWT.

Kreatif yang diartikan berpikir dan melakukan sesuatu untuk menghasilkan cara atau hasil baru dari sesuatu yang telah dimiliki (Wibowo, 2012:43), merupakan nilai selanjutnya. Kreatif lebih dikenal dengan sesuatu yang baru, sehingga orang yang kreatif akan selalu memunculkan ide-ide ataupun hasil karya baru yang tentunya bermanfaat baik bagi diri sendiri maupun orang lain.

Kemudian mandiri yang merupakan sikap dan perilaku yang tidak mudah bergantung pada orang lain dalam menyelesaikan tugas-tugas (Asmani, 2011:38). Mandiri akan memunculkan sikap kerja keras, tidak putus asa, dan mampu berpikir panjang dalam mengatasi masalah karena orang yang mandiri akan terus berusaha untuk melakukan segalanya sendiri meskipun terkadang memerlukan bantuan orang.

Nilai selanjutnya adalah demokratis. Itu merupakan cara berfikir, bersikap, dan bertindak yang menilai sama hak dan kewajiban dirinya dan orang lain (Asmani, 2011:40). Demokratis berarti sama rata, tidak membedakan hak dan kewajiban pada setiap individu.

Selanjutnya adalah rasa ingin tahu. Itu adalah sikap dan tindakan yang selalu berupaya untuk mengetahui lebih mendalam dan meluas dari sesuatu yang dipelajarinya, dilihat, dan didengar (Asmani, 2011:38). Rasa ingin tahu merupakan salah satu dorongan emosi yang berkaitan dengan perilaku, yaitu perilaku untuk menemukan hal-hal baru yang 
positif sehingga dari rasa ingin tahu tersebut seseorang akan bertambah pengetahuannya.

Semangat kebangsaan merupakan cara berpikir, bertindak dan berwawasan yang menempatkan kepentingan bangsa dan negara di atas kepentingan diri dan kelompoknya (Asmani, 2011:40). Semangat kebangsaan menumbuhkan sikap tidak egois yang hanya mementingkan kepentingan pribadi. Nilai ini menjadi nilai selanjutnya dalam pendidikan karakter.

Selanjutnya adalah Peduli sosial yang merupakan perilaku yang selalu ingin memberi bantuan pada orang lain dan masyarakat yang membutuhkan (Wibowo, 2012:44). Peduli sosial telah dianjurkan pula dalam Islam, sebagaimana QS. al-Kautsar:1-3 yang berbunyi:

Sesungguhnya Kami telah memberikan kepadamu nikmat yang banyak. Maka dirikanlah shalat karena Tuhanmu; dan berkorbanlah. Sesungguhnya orang-orang yang membenci kamu Dialah yang terputus.

Dampak positif dari peduli sosial menurut Triatmini (2011), antara lain terwujudnya sikap hidup gotong royong, terjalinnya hubungan batin yang akrab, menumbuhkan kerukunan dan kebersamaan, terjadinya pemerataan kesejahteraan, menghilangkan jurang pemisah antara si miskin dan si kaya, terwujudnya persatuan dan kesatuan, menciptakan kondisi masyarakat yang kuat dan harmonis, menghilangkan rasa dengki dan dendam.

Sikap peduli sosial berarti peduli sesama dan akan menumbuhkan sikap dermawan pada diri individu, karena masih banyak orang-orang yang kurang atau bahkan tidak mampu yang memerlukan bantuan. 
Nilai terakhir yang akan disebutkan disini adalah tanggung jawab, yaitu sikap dan perilaku seseorang untuk melaksanankan tugas dan kewajibannya sebagaimana yang seharusnya dia lakukan terhadap diri sendiri, masyarakat, lingkungan (alam, sosial, dan budaya), negara, dan Tuhan (Mustari, 2011:21). Tanggung jawab yang baik berada pada perimbangan yang serasi antara perolehan hak dan penuaian kewajiban. Sukanto dalam buku Nilai Karakter: Refleksi untuk Pendidikan Karkater, menyatakan bahwa diantara tanggung jawab yang harus ada pada manusia adalah tanggung jawab kepada Tuhan, untuk membela diri dari ancaman yang datang, tanggung jawab diri dari kerakusan ekonomi, terhadap keluarga, sosial kepada masyarakat sekitar, berpikir, dalam memelihara hidup dan kehidupan (Mustari, 2011:23)

\section{B. Komunitas Hijabers Salatiga}

Komunitas merupakan sekumpulan orang atau kelompok yang hidup dan saling berinteraksi di daerah tertentu; masyarakat; paguyuban (KBBI, 2003:586). Sedangkan hijabers yaitu berasal dari kata hijab dan ers. Hijab adalah bahasa arab yang berarti penutup, penghalang yang bisa juga dimaknakan sebagai kerudung atau penutup kepala. Sedangkan ers adalah kata yang merujuk pada perkumpulan, atau pengikut suatu komunitas atau komunitas tertentu. Komunitas hijabers adalah sekumpulan orang yang ingin terlihat sama dalam satu pandangan dalam bergaya dan berbusana yang berisikan wanita-wanita muslimah cantik dengan pakaian atau jilbab yang penuh gaya dan tidak biasa. Ia memodifikasi pakaian dan gaya berhijab agar lebih modis dan tidak 
terlihat atau dipandang kuno.Tujuan dibentuknya komunitas hijabers hijabers Salatiga yaitu untuk Menjadi komunitas yang berguna bagi sesama, serta menjadi wadah positif bagi muslimah untuk belajar dan saling berbagi.

Apabila seseorang masuk ke dalam suatu kelompok, pada umumnya ia tidak serta merta masuk dalam kelompok yang bersangkutan, tetapi ada tahapan-tahapan tertentu. Menurut Johnson (2000), ada beberapa tahap di mana orang akan masuk dalam kelompok yaitu:

Yang pertama adalah Prospective Member. Dalam tahapan ini, baik calon anggota maupun kelompok yang dimasuki masing-masing mengadakan evaluasi atau penilaian. Calon anggota akan melihat banyak hal baik yang akan menguntungkan ataupun merugikan dirinya didalam komunitas tersebut, sedangkan bagi kelompok yang dimasuki, memberikan informasi yang dibutuhkan oleh calon anggota.

Yang kedua adalah New Member. Tahapan ini, anggota baru akan menyesuaikan diri dengan hal-hal yang dituntut oleh kelompoknya. Ia akan memperoleh status dan peran dalam komunitasnya.

Tahapan ketiga adalah Full Member. Dalam tahapan ini, anggota yang sudah cukup mapan dalam kelompoknya sehingga memungkinkan memperoleh status dan peran yang berbeda dengan saat ia berkedudukansebagai new member.

Tahapan selanjutnya adalah Marginal member. Dengan segala perkembangan, anggota yang mungkin memiliki keraguan terhadap kelompok yang bersangkutan,anggota mungkin merasa sudah tidak 
cocok dengan norma-normayang sudah ada di dalam kelompoknya, sehingga iatidak sepenuh hati ada dalam kelompok yang bersangkutantersebut.

Yang terakhir adalah Ex-Member. Dalam tahapan ini anggota yang bersangkutan sudah tidak terkait pada kelompok semula dan ada kemungkinan iaberpindah ke kelompok lainnya.

Jika dalam komunitas Hijabers Salatiga, tahapan keanggotaan mereka melalui tahap Prospective Member, New Memeber, dan Full Member. Karena mereka yang tergabung dalam Hijabers Salatiga merasa banyak pengetahuan dan kegiatan yang diadakan selalu menarik, sehingga jarang dari mereka yang ke luar kecuali karena masalah keluarga.

\section{Persepsi Hijabers Tentang Pendidikan Karakter di Komunitas Hijabers Kota Salatiga}

Persepsi merupakan tanggapan atau pandangan seseorang mengenai sesuatu yang dialami oleh setiap individu. Persepsi hijabers tentang pendidikan karakter bermacam-macam, seperti pada beberapa informan yang telah dimintai keterangan melalui wawancara, ada yang mengatakan bahwa pendidikan karakter merupakan proses untuk menjadi diri sendiri, kemudian pendidikan untuk menjadikan pribadi yang lebih baik, sehingga pendidikan karakter adalah suatu proses pembentukan dan perubahan pada cerminan tiap individu agar lebih baik. Melalui pendidikan seseorang akan mendapatkan ilmu pengetahuan yang bermanfaat danagar tingkah laku seseorang dapat terarah kepadahal-hal 
yang positif. Selain pada jenjang pendidikan yang hijabers tempuh dalam membentuk dan mengembangkan karakter mereka, ternyata lingkunganpun memiliki pengaruh terhadap perkembangan karakter mereka. Seperti halnya komunitas hijabers kota Salatiga ini juga memiliki andil dalam pembentukan dan pengembangan karakter bagi para muslimah lainnya.Pembentukan dan pengembangan karakter yang dilakukan oleh hijabers lebih ditekankan pada penguatan agama dan penguatan solidaritas antar hijabers khususnya maupun masyarakat pada umumnya.

Teori karakter yang dikemukakan oleh Prof. Suyanto, Hermawan Kartajaya, Scerenko bahwa karakter adalah ciri khas yang dimiliki individu yang membedakan dengan yang lain. Teori-teori tersebut sejalan dengan yang dikemukakan oleh hijabers bahwa karakter adalah ciri khas yang melekat pada diri setiap orang. Karakter seseorang memang sulit dirubah tapi karakter itu dapat dibentuk sesuai dengan kondisi yang mempengaruhinya.

Teori pendidikan karakter yang dikemukakan oleh Lickona dan Scerenko sesuai dengan persepsi hijabers bahwapendidikan karakter merupakan suatu usaha untuk melakukan perubahan maupun pengembangan yang tercermin pada setiap individu untuk menjadi lebih baik.Sedangkan teori pendidikan karakter menurut Ratna Megawangi tidak sesuai dengan persepsi yang dikemukakan oleh hijabers. Melalui pendidikan karakter maka akan muncul nilai-nilai karakter pada hijabers dalam membentuk pribadi yang beradab diantaranya: religius, disiplin, 
kreatif, rasa ingin tahu, semangat kebangsaan, menghargai prestasi, peduli lingkungan, peduli sosial, dan tanggung jawab.

Pada komunitas Hijabers Salatiga pendidikan karakter yang mereka terapkan, diantaranya melalui beberapa event menarik. Hijabers Salatiga selain melalui fashion, mereka juga selalu mengadakan eventevent menarik yang membuat para muslimah untuk selalu mengikutinya, seperti event:

Event pertama adalah pendidikan karakter melalui trend masa kini yaitu fashion. Fashion merupakan gaya, model, cara berbusana. Pendidikan karakter melalui fashion/busana pada komunitas Hijabers Salatiga yaitu mereka mengadakan event-event tertentu yang di dalamnya mengajak para muslimah untuk berjilbab dan berpakaian sesuai syariat agama, dengan tidak menggunakan jilboobs (pakaian yang serba ketat). Pada Hijabers Salatiga diwajibkan bagi para anggota, pengurus itu menggunakan jilbab dan dilarang menggunakan jilboobs, jadi secara tidak langsung mereka secara perlahan-lahan membentuk karakter religius mereka dengan berbusana sesuai syar'i.

Event kedua adalah Hijab class and beauty class. Pada event seperti ini yang pernah dilakukan oleh Hijabers Salatiga sangat menarik dan banyak peserta muslimah yang mengikuti acara seperti ini bahkan sampai batas akhir untuk pendaftaran masih banyak yang mendaftar karena mereka memang ingin menambah pengetahuan dengan mengikuti event ini. Bahkan dari member Hijabers itu sendiri, tidak dari kalangan anak remaja saja bahkan sampai usia lansiapun banyak yang menjadi member Hijabers. Hijab classand beauty class ini dilaksanakan untuk 
membentuk karakter muslimah yang kreatif, semangat, rasa ingin tahu, menghargai prestasi.

Kreatif, merupakan berpikir dan melakukan sesuatu untuk menghasilkan cara atau hasil baru dari sesuatu yang telah dimiliki. Setiap yang tegabung dalam Hijabers Salatiga memiliki kreatif yang dikembangkan melalui event ini. Mungkin yang senang dengan make-up, dengan memadu padankan warna pakaian, selalu ingin tampil beda, dan lain sebagainya, ini bisa disalurkan melalui event seperti ini yang akan mengembangkan dan menumbuhkan potensi dalam dirinya.

Semangat, merupakan cara berpikir, bertindak dan berwawasan yang menempatkan kepentingan bangsa dan negara di atas kepentingan diri dan kelompoknya. Hijabers Salatiga dengan mengadakan kegiatan seperti ini karena mereka ingin berbagi pengetahuan kepada muslimah lainnya.

Rasa ingin tahu, merupakan sikap dan tindakan yang selalu berupaya untuk mengetahui lebih mendalam dan meluas dari sesuatu yang dipelajarinya, dilihat, dan didengar. Banyaknya peserta yang mengikuti kegiatan Hijabers Salatiga, ini menunjukkan bahwa banyak juga yang ingin tahu dengan kegiatan tersebut.

Menghasilkan sesuatu yang berguna bagi masyarakat, dan mengakui, serta menghormati keberhasilan orang lain. Para peserta muslimah akan menghargaihasil karya orang lain atau bahkan diapresiasi dalam bentuk mengikuti kegiatan yang dilakukan oleh Hijabers Salatiga. 
Acara selanjutnya yakni buka bersama dengan anak-anak Panti Asuhan pada bulan ramadhan. Acara buka bersama ini akan melahirkan nilai religius, peduli sosial, peduli lingkungan.

Religius, merupakan perilaku yang patuh dalam melaksanakan ajaran agama yang dianutnya, toleran terhadap pelaksanaan ibadah agama lain dan hidup rukun dengan pemeluk agama lain. Patuh terhadap perintah-Nya inilah yang dilakukan oleh Hijabers Salatiga dengan mengadakan pengajian/tausiah bersama untuk menumbuhkan sikap-sikap yang beradab sesuai dengan aturan agama.

Peduli sosial, merupakan perilaku yang selalu ingin memberi bantuan pada orang lain dan masyarakat yang membutuhkan. Kegiatan ini menunjukkan bahwa Hijabers Salatiga tidak seperti yang dikatan oleh orang-orang yang kontra dengan mereka. Kegiatan ini akan menumbuhkan sikp tenggang rasa, toleransi terhadap sesama. Acara ini juga tidak hanya berbuka bersama melainkan ada penggalangan dana juga yang nantinya akan disumbangkan kepada Panti-panti Asuhan dan orang yang membutuhkan.

Peduli lingkungan, merupakan sikap dan tindakan yang selalu berupaya mencegah kerusakan pada lingkungan alam di sekitarnya, dan mengembangkan upaya-upaya untuk memperbaiki kerusakan alam yang sudah terjadi. Hijabers Salatiga sadar bahwa kita hidup tidak hanya kelompok itusendiri dan masih banyak di luaran sana orang-orang yang membutuhkan kasih sayang dari kita semua yang cukup atau bahkan mampu untuk memperhatikan mereka yang kekurangan dan membutuhkan. 
Event selanjutnya adalah pengajian untuk komunitas itu sendiri, dan lain-lain. Pada kegiatan pengajian ini juga akan menumbuhkan sikap yang religius, komunikatif.

Religius, merupakan perilaku yang patuh dalam melaksanakan ajaran agama yang dianutnya, toleran terhadap pelaksanaan ibadah agama lain dan hidup rukun dengan pemeluk agama lain. Patuh terhadap perintah-Nya inilah yang dilakukan oleh Hijabers Salatiga dengan mengadakan pengajian/tausiah bersama untuk menumbuhkan sikap-sikap yang beradab sesuai dengan aturan agama.

Komunikatif, merupakan perilaku yang memperlihatkan rasa senang berbicara, bergaul, dan bekerja sama dengan orang lain. Acara pengajian ini dimaksudkan agar setiap anggota Hijabers Salatiga tidak memiliki batasan antara pengurus maupun anggota, merupakan salah satu cara agar setiap anggota dapat mengemukakan pendapatnya, tidak merasa canggung, dan agar lebih dekat satu sama lain.

Kegiatan yang dilakukan pada event-event tersebut tidak hanya sekedar kegiatan semata, melainkan untuk membentuk dan menumbuhkan karakter pada para muslimah.

\section{Model Pendidikan Karakter di Komunitas Hijabers Kota Salatiga}

Model pendidikan karakter yang ada di komunitas hijabers kota Salatiga, menggunakan dua penguatan, yaitu agama dan solidaritas.

Komunitas hijabers kota Salatiga yang diterapkan dalam penguatan agama hijabers yaitu dakwah melalui jilbab. Pemakaian jilbab 
bagi para muslimah sudah jelas diwajibkan dalam QS. al-Ahzab:59. Sesuai dengan ayat tersebut, maka hijabers berusaha untuk mengajak muslimah lainnya untuk mengenakan jilbab bagi yang belum berjilbab dan bagi yang sudah berjilbab agar lebih istiqomah dalam mengenakan jilbab. Hijabers dalam mengajak muslimah untuk berjilbab yaitu dengan berbagai event seperti hijab class, pada event ini hijabers memberi informasi mengenai jilbab dan memberikan beberapa model jilbab yang bisa dikenakan sesuai dengan situasi dan kondisi, dengan cara ini akan menarik muslimah lain agar tertarik untuk mengikuti event tersebut dan tertarik pula untuk mengenakan jilbab dengan gaya yang tidak ketinggalan zaman. Melalui penguatan agama inilah akan terbentuk karakter yang religius. Seseorang yang religius pasti akan selalu berusaha untuk mentaati segala perintah Tuhannya dan menjauhi segala yang dilarang-Nya sebagai bentuk ketaatan terhadap agamanya.

Penguatan solidaritas merupakan cara agar silaturahmi tetap selalu terjaga, dan melatih seseorang untuk bersosialisasi dengan baik antar sesama hijabers khususnya maupun dengan masyarakat luas umumnya. Penguatan solidaritas ini dapat dilakukan melalui beberapa event menarik dan positif tentunya, seperti fashion show, beauty class and hijab class, buka bersama di Panti Asuhan, dan lain sebagainya. Dengan mengadakan event-event di hijabers, secara tidak langsung melatih mereka untuk berinteraksi dengan orang lain dengan cara yang sopan, akrab yang disesuaikan dengan lawan bicaranya, menjadikan hijabers menghargai orang lain, dan lain sebagainya. Melalui penguatan solidaritas ini akan terbentuk karakter bersahabat/komunikatif, peduli 
sosial, menghargai prestasi, tanggung jawab, disiplin. (Sumber: data hasil observasi)

\section{E. Faktor-faktor Penghambat dan Pendorong Pendidikan Karakter di Komunitas Hijabers Kota Salatiga}

Faktor-faktor yang menjadi penghambat tidak hanya berada pada jenjang pendidikan namun lingkunganpun mempengaruhi, begitu pula yang dialami di Komunitas Hijabers Salatiga yang memiliki hambatan dalam melaksanakan pendidikan karakter.

Faktor penghambat pertama adalah sulit untuk kumpul. Pada masalah ini memang setiap individu memiliki kesibukan dan aktivitas masing-masing, namun ini memang sudah menjadi keputusan mereka untuk bergabung dengan Hijabers Salatiga sehingga hijabers harus siap dengan konsekuensi yang ada. Sulit untuk kumpul yang dimaksud adalah ketika Hijabers Salatiga akan mengadakan event, secara otomatis sebelum pelaksanaan event tersebut harus mendiskusikan rancangannya terlebih dahulu namun banyak yang tidak hadir untuk mendiskusikan rencana kegiatan tersebut, seperti yang diungkapkan oleh ML.

Kalau hambatan di Hijabers Salatiga itu sendiri yaitu kita jarang kumpul, kadang ada jadwal kumpul tapi yaa yang gak berangkat juga banyak" (Wawancara 20 Agustus 2015, pukul 16.00 WIB).

Pernyataan ML jelas bahwa rasa peduli sosial dan tanggung jawab mereka menjadi kurang dengan tidak mengikuti rapat-rapat seperti itu.

Faktor penghambat yang kedua adalah melalaikan tanggung jawab. Tanggung jawab merupakan sesuatu kepercayaan yang dipegang oleh seseorang. Tanggung jawab melahirkan sifat kepercayaan. Namun 
pada Hijabers Salatiga ini menjadi salah satu kendala dalam membentuk karakter seseorang, karena orang yang diberi tugas itu melalaikan kewajibannya. Seperti yang dikatakan oleh D OSSY.

Kendala yang ada di Hijabers Salatiga itu, ketika seseorang diberi tugas dibagian pendaftaran dan ternyata orang itu belum datang padahal peserta sudah banyak yang datang, jadinya kan teman-teman yang bertugas menjaga stand yang lain harus menjaga juga di stand yang belum ada petugasnya" (Wawancara 14 Agustus 2015, pukul 15.20 WIB).

Tanggung jawab itu dituntut juga untuk disiplin, baik itu disiplin waktu maupun keadaan agar orang lain tidak kesulitan yang menjadi bukan tanggung jawabnya.

Faktor penghambat berikutnya adalah kurangnya disiplin. Disiplin menentukan suatu keberhasilan, oleh karena itu Hijabers Salatiga dituntut untuk disiplin dalam menjalankan setiap kegiatan yang menjadi tanggung jawabnya. Misalnya di Hijabers Salatiga seperti disiplin waktu.

Kendala selanjutnya adalah kurangnya keterbukaan dari tiap individu, seperti yang diungkapkan oleh TR dan AH.

Kendala yang ada di Hijabers itu selain susah untuk diajak kumpul, juga kurang terbuka satu sama lain yang akhirnya terjadi beda pendapat dan gak bisa maksa seseorang untuk sama dengan jiwa Hijabers Salatiga" (Wawancara 13, 15 Agustus 2015).

Terbuka merupakan hal yang sepele tapi penting untuk dilakukan. Oleh karena itu sikap terbuka diperlukan dalam Hijabers Salatiga untuk 
menyamakan pendapat dan menyampaikan aspirasi-aspirasi dari tiap individu agar kegiatan dapat sukses dan berjalan lancar.

Pro-kontra mengenai Hijabers juga menjadi faktor penghambat. Banyak opini-opini yang mengatakan bahwa Hijabers itu identik dengan kecantikan, glamour dalam berbusana, nongkrong di tempat-tempat yang mewah, hura-hura, dan lain sebagainya yang menunjukkan bahwa Hijabers itu kumpulan orang-orang hight class. Setiap event yang disajikan dipandang negatif, seperti kegiatan Hijabers khususnya Hijabers Salatiga itu dipandang hanya memamerkan kekayaan, kecantikan, dan fashion yang menyimpang dari syar'i. Namun ada juga yang pro dengan Hijabers khususnya Hijabers Salatiga yang berharap untuk adanya event baru lagi dari Hijabers Salatiga yang diadakan, karena event yang dilakukan oleh Hijabers Salatiga sangat menarik dan kekinian sehingga tidak dikatakan kuno/ketinggalan zaman.

Faktor-faktor penghambat di atas dapat disimpulkan bahwa yang menjadi penghambat dalam menerapkan pendidikan karakter, yaitu ada beberapa alasan salah satunya karena ada pandangan dari masyarakat bahwa hijabers itu kumpulan yang hight class sehingga ada diantara mereka sulit untuk menyesuaikan misal dari penampilan mereka, seperti yang penulis rasakan meskipun hanya beberapa kali melakukan pertemuan dan ketika akan bertemu dengan hijabers tentu akan memikirkan penampilan apakah sudah sesuai dengan hijabers atau belum, mungkin itu juga yang dirasakan oleh anggota hijabers.Sedangkan faktor pendorong untuk melakukan pendidikan karakter pada Komunitas Hijabers Salatiga, yaitu sesuai dengan visi, 
misi, dan tujuan mereka untuk berdakwah melalui hijab, dan memperdalam ilmu pengetahuan tentang Islam.

\section{F. Solusi dalam Mengatasi Faktor-faktor Penghambat Pendidikan Karakter pada Muslimah di Komunitas Hijabers Kota Salatiga}

Dari faktor-faktor pengambat di atas, pastinya ada solusi-solusi yang dapat dilakukan untuk mengatasinya, karena setiap masalah yang ada pasti selalu dengan solusi yang diberikan. Alternatif solusi tersebut, diantaranya adalah diusahakan untuk berkumpul dan sharing-sharing serta semua harus terbuka tentang hal-hal yang mengenai Hijabers Salatiga. Sedangkan untuk tanggung jawab bisa dilakukan dengan pergantian penanggung jawab dalam setiap event, sehingga semua pengurus dapat merasakan dari setiap tugas yang dipegangnya. Solusi yang lain adalah melakukan pendekatan melalui sikap empati bukan dengan simpati, dengan empati kita dapat memahami apa yang mereka inginkan dan harus memahami pula pola pikir orang-orang yang kontra dengan Hijabers tersebut.

\section{Kesimpulan}

Pendidikan karakter yang dikemukakan oleh hijabers merupakan suatu proses pembentukan dan perubahan pada cerminan tiap individu agar lebih baik. Model Pendidikan Karakter di Komunitas Hijabers Kota Salatiga melalui dua penguatan, yaitu penguatan agama dan penguatan solidaritas. 
Ada beberapa faktor yang menghambat Hijabers Salatiga dalam menerapkan pendidikan karakter diantaranya sulit untuk kumpul, melalaikan tanggung jawab, kurangnya disiplin, kurangnya keterbukaan, pro-kontra mengenai Hijabers. Kemudian ada juga faktor pendorong Hijabers Salatiga untuk menerapkan pendidikan karakter tersebut yaitu karena tujuan dan visi serta misi mereka yang ingin mendakwahkan hijab melalui komunitas Hijabers.

Solusi dalam mengatasi penghambat-penghambat tersebut yaitu diusahakan untuk kumpul dan sharing, terbuka, pada setiap event yang menjadi penanggung jawab harus bergantian, dan melalui pendekatan empati bukan sekedar simpati. Komunitas Hijabers khususnya Hijabers Salatiga tidak semata-mata hanya memamerkan kecantikan, menunjukkan mereka itu kalangan high class tapi dibalik pro-kontra mengenai Komunitas Hijabers khususnya Hijabers Salatiga mereka juga berusaha membentuk dan mengembangkan karakter agar menjadi lebih baik lagi.

\section{Daftar Pustaka}

Adi, Isbandi Rukminto. 1994. Psikologi, Pekerjaan Sosial dan Ilmu Kesejahteraan Sosial: Dasar-dasar Pemikiran. Jakarta: PT RajaGrafindo Persada.

Ahmadiansah, Reza. 2010. Persepsi Mahasiswa STAIN Salatiga Tentang Busana Muslimah. Skripsi tidak diterbitkan. Salatiga: Tarbiyah STAIN Salatiga.

Asmani, Jamal Ma'mur. 2011. Buku Panduan Internalisasi Pendidikan Karakter di Sekolah. Jogjakarta: DIVA Press.

Cokroaminoto. 2011. Jenis dan Pendekatan Penelitian Kualitatif, (Online), 
Mudarrisa: Jurnal Kajian Pendidikan Islam, Vol. 7, No. 1, Juni 2015: 29-58

(http://www.menulisproposalpenelitian.com/2011/01/jenis-jenispenelitian-kualitatif.html, diakses 1 Oktober 2015).

Depdiknas. 2003. Kamus Besar Bahasa Indonesia (Edisi Ketiga). Jakarta: Balai Pustaka.

Gunawan, Heri. 2012. Pendidikan Karakter: Konsep dan Implementasi. Bandung: Alfabeta.

Handayani, Sri. 2012. Kepedulian Lingkungan, (Online), (http://mamagilang.blogspot.com/2012/11/kepedulianlingkungan.html, diakses 13 Agustus 2015).

Hidayatullah, Furqon. 2010. Pendidikan Karakter: Membangun Peradaban Bangsa. Surakarta: Yuma Pustaka.

Ikhsan, Fuad. 2003. Dasar-Dasar Kependidikan. Jakarta: Rineka Cipta. Kesuma, Dharma, dkk. 2012. Pendidikan Karakter: Kajian Teori dan Praktik di Sekolah. Bandung: Rosdakarya.

Moleong, Lexy J. 2009. Metodologi Penelitian Kualitatif. Bandung: Remaja Rosdakarya.

Muchlas Samani \& Hariyanto, M.S.. 2013. Konsep dan Model Pendidikan Karakter. Bandung: Remaja Rosdakarya.

Mufidah, Dewi. 2012. Implementasi Nilai-nilai Budaya Bangsa dalam Pembelajaran Pendidikan Agama Islam di Sekolah Menengah Atas Islam Sudirman Ambarawa Tahun Pelajaran 2011/2012. Skripsi tidak diterbitkan. Salatiga: Tarbiyah STAIN Salatiga.

Muidin. 2015. Membangun Karakter Sejak Usia Dini. Maudiku, hlm.27.

Mulyana, Deddy. 2000. Ilmu Komunikasi Suatu Pengantar. Bandung: PT Remaja Rosdakarya.

Munir, Abdullah. 2010. Pendidikan Karakter: Membangun Karakter Anak Sejak dari Rumah. Yogyakarta: Pedagogia.

Muslich, Masnur. 2011. Pendidikan Karakter: Menjawab Tantangan Krisis Multidimensional. Jakarta: Bumi Aksara.

Mustari, Mohamad. 2011. Nilai Karakter: Refleksi Untuk Pendidikan Karakter. Yogyakarta: PRESSindo.

Republika. 18 Juli 2015. Menteri Anies Kemukakan Lima Komponen Pendidikan Karakter, (Online), (http://www.pendidikanguru.com/index.php/2015/07/18/menterianies-kemukakan-lima-komponen-pendidikan-karakter/, diakses 7 Agustus 2015).

Sugiyono. 2006. Metode Penelitian Kuantitatif Kualitatif dan $R \& D$. Bandung: Alfabeta. 
Triatmini. 2011. Kepedulian Sosial, (Online), (http://pembelpai.blogspot.com/2011/01/bab-iii-kepeduliansosial.html, diakses 13 Agustus 2015).

Wahyuningsih, Esti. 2013. Pendidikan Karakter untuk Membangun Perilaku Positif Anak Sekolah Dasar, (Online),(http://estiprihantara.blogspot.com/2013/05/pendidikankarakter.html, diakses 6 Agustus 2015).

Wibowo, Agus. 2012. Pendidikan Karakter: Strategi Membangun Karakter Bangsa Berperadaban. Yogyakarta: Pustaka Pelajar.

Zubaedi. 2011. Design Pendidikan Karakter: Konsepsi dan Aplikasinya dalam Lembaga Pendidikan. Jakarta: KENCANA.

Zuchdi, Damayanti, dkk. 2013. Pendidikan Kerakter: Konsep Dasar dan Implementasi di Perguruan Tinggi. Yogyakarta: UNY Press.

Zuchdi, Darmiyati, dkk. 2011. Pendidikan Karakter dalam Perspektif Teori dan Praktik. Yogyakarta: UNY Press.

Zulfa, F. 2013. Pendidikan Karakter, diakses dari http://digilib.uinsby.ac.id/10872/5/bab\%202.pdf, tanggal 14 Mei 15. 
Mudarrisa: Jurnal Kajian Pendidikan Islam, Vol. 7, No. 1, Juni 2015: 29-58 